\title{
Identification of Novel Mutations in LCT-Gene of Pakistani Patients with Lactose Non-persistence
}

\author{
Maria Qibtia $^{1}$, Muhammad Wasim ${ }^{1}$, Farzana Chowdhary ${ }^{1}$, Muhammad Tayyab ${ }^{1}$, \\ Sehrish Faryal ${ }^{1}$, Ahmed Mansouri' ${ }^{2}$, Zeeshan Ahmad ${ }^{2}$, Muhammad Hamid ${ }^{3}$ and \\ Ali Raza Awan ${ }^{1, *}$ \\ ${ }^{1}$ Institute of Biochemistry and Biotechnology, University of Veterinary and Animal \\ Sciences, Shaykh Abdul Qadir Jilani Road, Data Gunj Buksh Town, Lahore, Pakistan \\ ${ }^{2}$ Max-Planck Institute for Biophysical Chemistry, Molecular Cell Differentiation Group, \\ Am Fassberg 11, 37077 Göttingen, Germany \\ ${ }^{3}$ University of Ulm, Energiewandlung und Speicherung, Albert Einstein Allee 47, 89081 \\ Ulm, Germany
}

\section{A B S T R A C T}

Lactose non-persistence (LNP) develops due to the downregulation of the lactase-phlorizin hydrolase (LPH) enzyme. LPH is encoded by the $L C T$-gene located on chromosome 2q21. In this study, 50 patients with LI were investigated for the identification of mutations in the $L C T$-gene. In comparison of 30 subject with lactose persistence (LP) considered as healthy group. A total of 13 genomic mutations were identified, 1 in the promoter region and 12 in the intronic/exonic region of $L C T$-gene. Among these 12 mutations, 6 of them are novel in origin. The novel mutations were found in intron 4 c. $(918+116) A>C$, intron 12 c. $(4877+20) \mathrm{G}>\mathrm{A}$, intron 15 c. $(5346+35) \mathrm{T}>\mathrm{C}$, UTR of exon 17 (c. $5865 \mathrm{C}>\mathrm{T})$, exon 6 c. $1147 \mathrm{~A}>\mathrm{G}$ and c. $1095 \mathrm{~A}>\mathrm{G}$. Four mutations resulted in an altered amino acid sequence. The frequency of each mutation observed in both gruops was: mutation I of exon $1(0.64 / 1)$, mutation II of exon $2(0.34 / 0.67)$, mutation III, IV and V of exon $6(1 / 1,0.12 / 0,0.64 / 1)$ mutation VI of exon $13(0.64 / 1)$, mutation VII, VIII, IX of exon $17(0.64 / 1,1 / 1,0.12 / 0)$, mutation X of intron $4(0 / 1)$, mutation XI of intron $12(1 / 0)$, mutation XII of intron $15(1 / 1)$ and mutation XIII of promoter region $(0.36 / 0.67)$. In this study, molecular identification and screening in LNP subjects provide the mutational variants of the LCT-gene in the region of Pakistan. This is a major step in clinical management and accurate genetic counseling of the pre-symptomatic diagnosis of LNP. Among the six novel mutations found, mutation XI was found in all of the LNP subjects and was absent in the lactose persistent group. This study, for the first time, focuses on molecular analysis of $L C T$-gene from Pakistani patients with LNP.
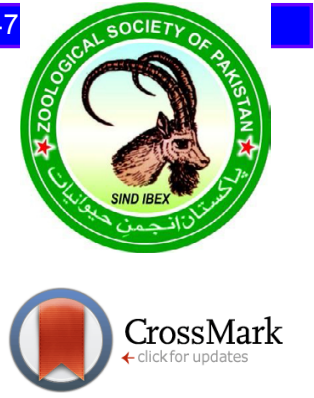

\begin{tabular}{l} 
Article Information \\
Received 02 January 2020 \\
Revised 17 February 2020 \\
Accepted 04 March 2020 \\
Available online 14 October 2020 \\
Authors' Contribution \\
MQ conceived the idea, performed \\
the experiments, wrote manuscript \\
and compiled the first draft. MW and \\
FC were the members of supervisory \\
committee. MT analyzed the data. SF \\
was lab incharge. AM supervised in \\
Max-Planck Institute.ZA assisted and \\
guided in lab work performed. MH \\
helped in manuscript writing.ARA \\
designed and susupervised the study. \\
Key words \\
\hline Lactose non-persistence, Lactose \\
persistence, Lactase Phlorizin \\
Hydrolase, Un-translated area, Cis- \\
Acting factor.
\end{tabular}

Article Information

Received 02 January 2020

Revised 17 February 202

Accepted 04 March 2020

Authors' Contribution

the conceived the idea, performed and compiled the first draft. MW and

FC were the members of supervisory committee. MT analyzed the data. SF was lab incharge. AM supervised in Max-Planck Institute.ZA assisted and helped in manuscript writing.ARA designed and susupervised the study.

Lactose non-persistence, Lactos persistence, Lactase Phlorizin Acting factor.

\section{INTRODUCTION}

L actose non-persistence (LNP) (OMIM\#223100) is a genetically determined, developmental phenomenon, which occurs after weaning in different populations (EFSA, 2010). LNP is a phenotypic enzyme deficiency caused by decreased lactase enzyme production. It can cause different kinds of intestinal and systemic symptoms: headache, vomiting, nausea, flatulence, abdominal pain, gut distension, diarrhea, constipation, loss of concentration, muscle pain, allergies, heart arrhythmia, mouth ulcers, sore throat and increased Micturition (Asmawi et al., 2006; Babu et al., 2010; EFSA, 2010; Freund et al., 1989; Hovde et al., 2009; Montgomery et al., 1991; Potter et al., 1985; Sahi et al., 1983; Welsh, 1970). Most of the studies related to LNP were reported from Finnland. According to one of

\footnotetext{
Corresponding author: arawan77@uvas.edu.pk 0030-9923/2021/0001-0001 \$ 9.00/0

Copyright 2021 Zoological Society of Pakistan
}

the reports, Finnish children had an onset age from 0-20 years (Rasinpera et al., 2004; Vesa et al., 2000). Whereas in the present study, the reported age of onset for this enzymatic deficiency varies from 2-17 years (Cook, 1967; Lehtimaki et al., 2006), the highest prevalence in Pakistani patients was found in the range of 2-5 years. In the past, LNP was diagnosed with help of tests like glucose-oxidase test, blood glucose test, lactose tolerance test, glucosegalactose tolerance test, urinary galactose test, stool $\mathrm{pH}$ and breath hydrogen test. All of these tests did not provide reliable results (EFSA, 2010; Asmawi et al., 2006; Hovde et al., 2009; Sahi et al., 1983; Bayless et al., 1966; Boll et al., 1991; Cuatrecasas et al., 1965; Dahlqvist, 1961; Ferguson and Maxwell, 1967; Gray et al., 1969; Krawczyk et al., 2008; Lee et al., 1998; Lukito et al., 2015; Raz et al., 2013; Sahi et al., 1973; Sahi, 2001; Tandon et al., 1981; Tomar, 2014; Witte et al., 1990). However, with the advent of PCR and genetic marker analysis techniques, the research work of Scandinavian countries, the United States and Europe were concluded by analyzing various 
aspects of $L C T$-gene along with its cis-acting factors. All these researches used various tests in comparison of genetic markers in order to give a final conclusion about the diagnosis, prevention, treatment and mechanism in development of LNP (Burger et al., 2007; Campbell et al., 2005; Enattah et al., 2008; Jarvela et al., 2003; Krawczyk et al., 2008; Miquel et al., 2011; Rasinpera et al., 2004; Raz et al., 2013; Sahi et al., 1983; Sahi, 2001; Semenza et al., 1989; Swallow, 2003; Szilagy et al., 2007; Tandon et al., 1981; Tarabra et al., 2010; Troelsen, 2005; Vesa et al., 2000).

\section{MATERIALS AND METHODS}

Formal approval was obtained from Institutional Review Board (IRB), at the Institute of Biochemistry and Biotechnology (IBBT), University of Veterinary and Animal Sciences (UVAS) Lahore, Pakistan Vide Letter No DAS/3067 dated 11.12.12. The NCBI Reference Sequence used was NC_000002.12 (www.ncbi.nlm.nih. gov/gene/3938). Written informed consent was taken from the LNP patients specifically belonging to Province Punjab of Pakistan, blood samples of 50 patients were collected. All these cases were diagnosed for LNP based intolerance symptoms after drinking milk. Blood DNA samples of 30 healthy subjects from Punjab were also collected as a control group. The DNA extraction was performed on whole blood according to the standard phenol-chloroform extraction method (Sambrook and Russel, 2012). The equipment used for this process is "Thermo Scientific Gene JET Whole Blood Genomic DNA Purification Mini Kit" \#K0781, \#K0782 Pub. No. MAN0012667 manufactured by Thermo Fisher Scientific Inc. The software for designing the primers, of the $L C T$-gene and promoter region were:'Primer 3', 'ApE', Clustalw and others reported by Ranciaro et al. (2014) as shown in Table I. The rest of the work was compiled in the research lab of the Max-Planck Institute for Biophysical Chemistry, Gottingen, Germany. A PCR approach similar to that adopted by Ranciaro with an annealing temperature of $60^{\circ} \mathrm{C}$ for intron spliced exons and $61.5^{\circ} \mathrm{C}$ for the promoter region (Ranciaro et al., 2014) was implemented, which amplifies and performs melting analysis. After PCR amplification, PCR products showing a clear band of required lengths, purification was done using GENECLEAN Spin Kit for rapid and user-friendly purification of DNA in three basic steps. The PCR products were eluted with $15 \mu$ l elution buffer and diluted 1:10 with water. The sequencing was done using an automated ABI PRISM 3100 Genetic Analyzer (SeqLab, Germany). Sequencing data results were analyzed by using $\mathrm{ApE}$ a plasmid editor software.

Table I.- Primers used for $L C T$-gene amplification.

\begin{tabular}{llllc}
\hline No. & Primer & Sequence (5'-3') Forward & Sequence (5'-3') Reverse & Size (Bp) \\
\hline 1 & EXON 1 & TATTGCATTAGTGAACCGTGTACTG & TAGCTACCCCTTCCTATCGCC & 953 \\
2 & EXON2 & CAACTGCTCTGCATTTCATAGTCC & GAAGCTGACACTTGACCAAGCA & 495 \\
3 & EXON3 & ACACACACACACACACACAC & CCCCATTGATGAGTTGCCTT & 700 \\
4 & EXON4 & AAGAAGAGGTGAAGGTGGGG & TCCCCTGACTTGATTGGACC & 1050 \\
5 & EXON5 & TTAAAGTCGTTAGCCCATGGT & TAGCTGGGACCATAGGCATG & 970 \\
6 & EXON6 & CTCAGTGTTTCTGGAATCTTTC & CTTGCTGATGGAAGAAAACAGAG & 925 \\
7 & EXON7 & TGGTTCATTAGTCCTGTTGTTGT & GAAGTACCACCCACCTTCCA & 840 \\
8 & EXON8 & ACTTGTTTGACAGCTCGCAG & TGGAGTTGGGACCTAAGAGAG & 920 \\
9 & EXON9 & CTTGAATTGAGGAGCTGGCA & CCATGGGTCTGCTGGAATCT & 700 \\
10 & EXON10 & AAGGAGGCTGTGAGTGCTTG & TGATAAATGTGCTCCCCCAGC & 425 \\
11 & EXON11 & CCCATGGAAAGCATGACTGA & CAGAGAGCTTCCCACCTGAG & 700 \\
12 & EXON12 & CTGCCCATTTCACCAAGGAG & CCAAGCTCACAAAATCAGGC & 848 \\
13 & EXON13 & GTGGACACTGAAGCTGCAACAG & CCAGCAAGCAAAGAAGCTCAGT & 376 \\
14 & EXON14 & GACCTAGGGAAGCCAGGTTT & TTCTCTCCCTCTTGCTTGCT & 700 \\
15 & EXON15 & GGCTTTTCCTGGTCTAAGTCC & TCTCTTCTTACTGTGGCCCA & 422 \\
16 & EXON16 & ACTGCATGCAAAGAAAGGGG & AAACAGACTGAGAGAGGCCC & 700 \\
17 & EXON17 & TCAATGGCTGTGCGGATTTG & AGACCCTAAGGTGTTTGGTGG & 410 \\
18 & LCT-P1 & TTGAACCCAAGAGGTGGAAG & TGCCATATGTATTTTCAGCCTTT & 783 \\
19 & LCT-P2 & GGGCTTGAGCAGTCCTACAG & TTGACTTCCTGGGCTCAAGT & 953 \\
20 & LCT-P3 & AGAGAAAATTTGGGGCAAAATAC & ACCCCCAGCATGAAAAACTT & 980 \\
\hline
\end{tabular}

*From Ranciaro et al. (2014). 


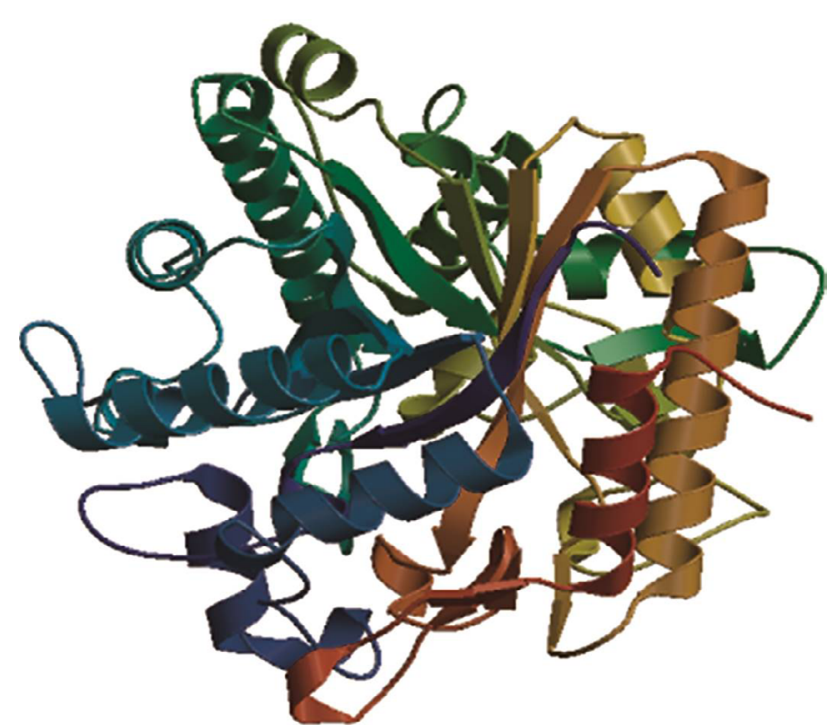

Fig. 1. Molecular model of LCT-gene (NCBI) 2012.

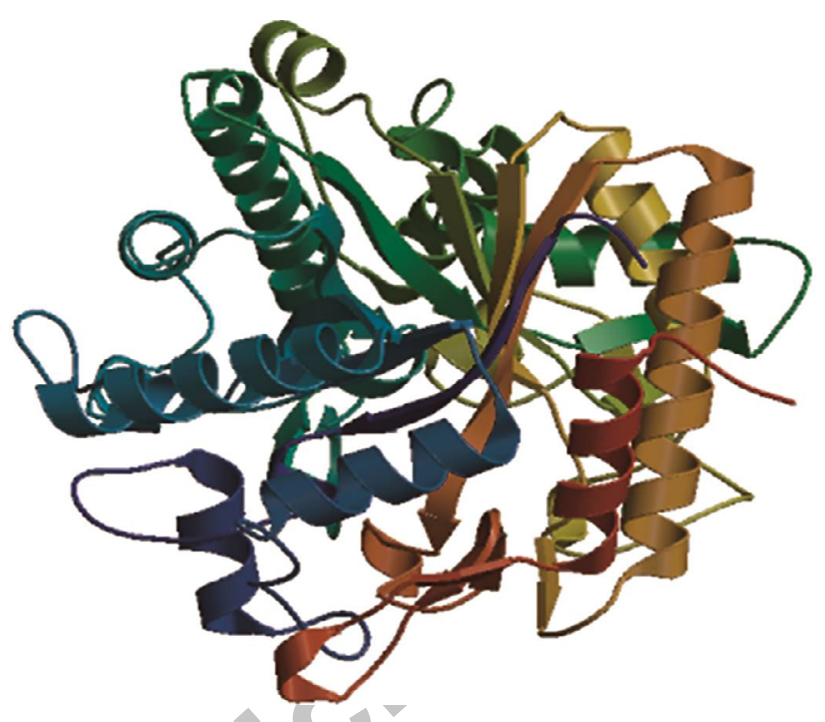

Fig. 2. Predicting molecular modeling of $L C T$-gene with alterations.

Table II.- Mutations in LCT-gene associated with lactose non-persistence/lactose persistence.

\begin{tabular}{|c|c|c|c|c|c|c|c|c|c|}
\hline $\begin{array}{l}\text { Muta- } \\
\text { tion } \\
\text { No. }\end{array}$ & $\begin{array}{l}\text { Mutation } \\
\text { position }\end{array}$ & Variant & $\begin{array}{c}\text { Exonic/ } \\
\text { intronic/ } \\
\text { promoter }\end{array}$ & $\begin{array}{c}\text { Novel/ } \\
\text { reported }\end{array}$ & $\begin{array}{l}\text { Frequency- } \\
\text { LNP/LP }\end{array}$ & $\begin{array}{l}\% \text { in LNP (\% } \\
\text { heterozygosity) }\end{array}$ & $\begin{array}{c}\% \text { in LP (\% } \\
\text { heterozygosity) }\end{array}$ & $\begin{array}{l}\text { Change in } \\
\text { amino acid }\end{array}$ & $\begin{array}{c}\mathrm{P}- \\
\text { value }\end{array}$ \\
\hline I & $\begin{array}{l}\text { c. } 593 C>T \\
\text { g. } 593 C>T\end{array}$ & $\mathrm{C}>\mathrm{T}$ & Exon 1 & $\mathrm{R}$ & $0.64 / 1$ & $64(20 \%)$ & $100(66 \%)$ & - & 0 \\
\hline II & $\begin{array}{l}\text { c. } 666 \mathrm{G}>\mathrm{A} \\
\text { g. } 4005 \mathrm{G}>\mathrm{A}\end{array}$ & $\mathrm{G}>\mathrm{A}$ & Exon 2 & $\mathrm{R}$ & $0.34 / 0.67$ & $34(100 \%)$ & $66(100 \%)$ & Val 219 Ile & 0.005 \\
\hline III & $\begin{array}{l}\text { c. } 1095 \mathrm{~A}>\mathrm{G} \\
\text { g. } 19206 \mathrm{~A}>\mathrm{G}\end{array}$ & $\mathrm{A}>\mathrm{G}$ & $F$ & $\mathrm{~N}$ & $1 / 1$ & $100(0 \%)$ & $100(0 \%)$ & Ile $362 \mathrm{Val}$ & - \\
\hline V & $\begin{array}{l}\text { c. } 1430 C>A \\
\text { g. } 19541 C>A\end{array}$ & $>\mathrm{A}$ & Exon 6 & $\mathrm{R}$ & $0.64 / 1$ & $64(0 \%)$ & $100(33 \%)$ & - & 0 \\
\hline IV & $\begin{array}{l}\text { c. } 1147 \mathrm{~A}>\mathrm{G} \\
\text { g. } 19258 \mathrm{~A}>\mathrm{G}\end{array}$ & $A>G$ & Exon 6 & $\mathrm{~N}$ & $0.12 / 0$ & $12(100 \%)$ & NIL & Glu 379Arg & 0.049 \\
\hline VI & $\begin{array}{l}\text { c. } 4927 \mathrm{~A}>\mathrm{G} \\
\text { g. } 39081 \mathrm{~A}>\mathrm{G}\end{array}$ & $\mathrm{A}>\mathrm{G}$ & Exon 13 & $\mathrm{R}$ & $0.64 / 1$ & $\begin{array}{c}64 \\
(20 \%)\end{array}$ & $100(33 \%)$ & Asn 1639 Ser & 0.001 \\
\hline VII & $\begin{array}{l}\text { c. } 5579 \mathrm{~T}>\mathrm{C} \\
\text { g. } 48360 \mathrm{~T}>\mathrm{C}\end{array}$ & $\mathrm{T}>\mathrm{C}$ & Exon 17 & $\mathrm{R}$ & $0.64 / 1$ & $\begin{array}{c}64 \\
(10 \%)\end{array}$ & $100(66 \%)$ & - & 0.001 \\
\hline VIII & $\begin{array}{l}\text { c. } 5845 \mathrm{G}>C \\
\text { g. } 48896 \mathrm{G}>\mathrm{C}\end{array}$ & $\mathrm{G}>\mathrm{C}$ & Exon 17 & $\mathrm{R}$ & $1 / 1$ & $\begin{array}{c}100 \\
(44 \%)\end{array}$ & $100(66 \%)$ & - & - \\
\hline IX & $\begin{array}{l}\text { c. } 5865 C>T \\
\text { g. } 48916 C>T\end{array}$ & $\mathrm{C}>\mathrm{T}$ & Exon 17 & $\mathrm{~N}$ & $0.12 / 0$ & $\begin{array}{c}12 \\
(0 \%)\end{array}$ & NIL & - & 0.049 \\
\hline XII & $\begin{array}{l}\text { c. }(5346+35) \mathrm{T}>\mathrm{C} \\
\text { g. } 49004 . \mathrm{T}>\mathrm{C}\end{array}$ & $\mathrm{T}>\mathrm{C}$ & Intron 15 & $\mathrm{~N}$ & $1 / 1$ & $\begin{array}{l}100 \\
(0 \%)\end{array}$ & $100(0 \%)$ & - & - \\
\hline $\mathrm{X}$ & $\begin{array}{l}\text { c. }(918+116) A>C \\
\text { g. } 15842 A / C\end{array}$ & $\mathrm{~A}>\mathrm{C}$ & Intron 4 & $\mathrm{~N}$ & $0 / 1$ & NIL & $100(0 \%)$ & - & - \\
\hline XI & $\begin{array}{l}\text { c. }(4877+20) G>A \\
\text { g. } 39039 G>A\end{array}$ & $\mathrm{G}>\mathrm{A}$ & Intron 12 & $\mathrm{~N}$ & $1 / 0$ & $\begin{array}{l}100 \\
(0 \%)\end{array}$ & 0 & - & 0.05 \\
\hline XIII & $\begin{array}{l}\text { c. }-956 \mathrm{C}>\mathrm{T} \\
\text { g- } 956 \mathrm{C} / \mathrm{T}\end{array}$ & $\mathrm{C}>\mathrm{T}$ & Promoter & $\mathrm{R}$ & $0.36 / 0.67$ & $36(100 \%)$ & $66(100 \%)$ & - & 0.008 \\
\hline
\end{tabular}



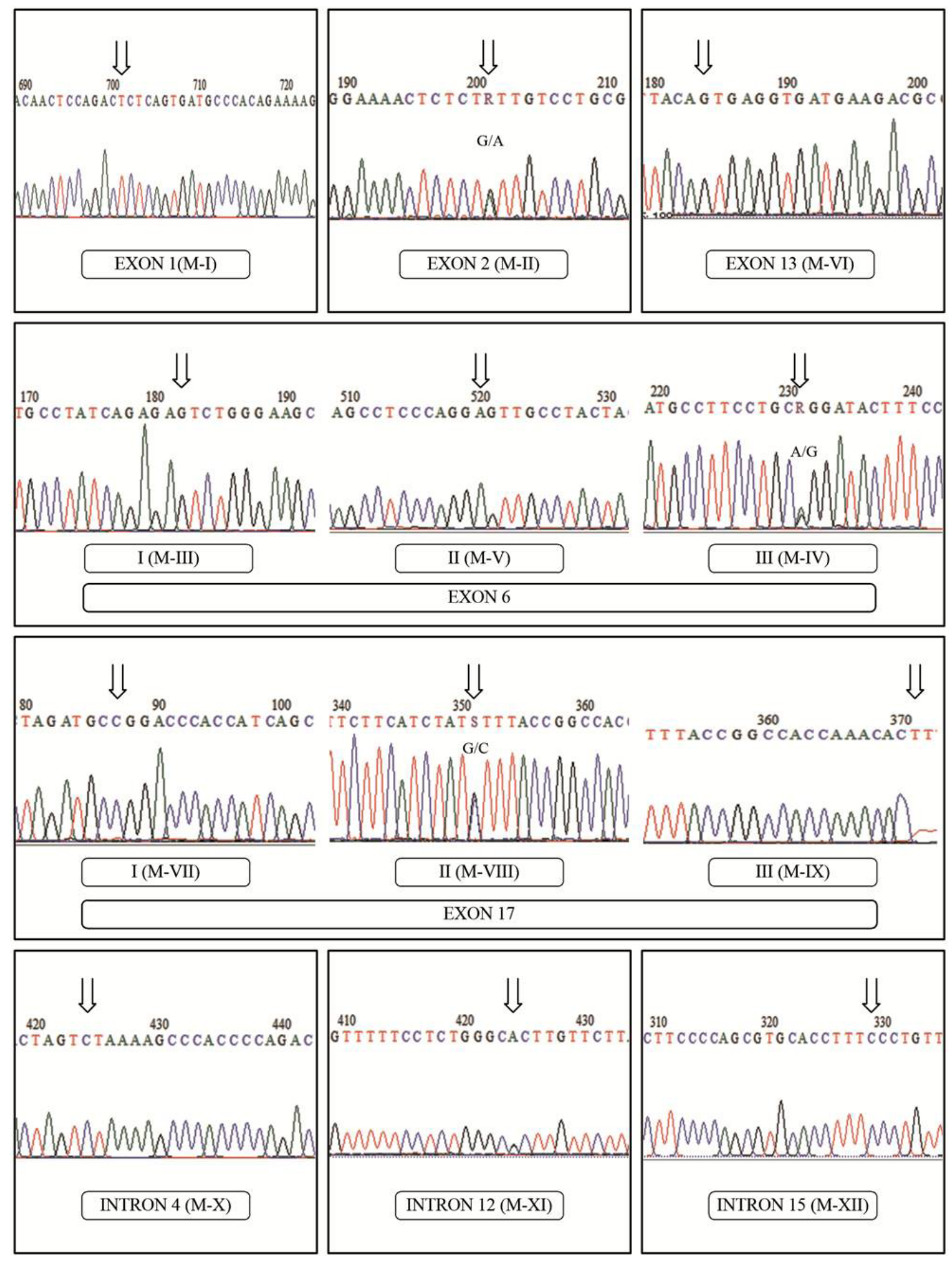

Fig. 3. Exonic and intronic alterations in $L C T$-gene 


\section{RESULTS}

A total of thirteen genomic mutations were identified in the $L C T$-gene, including three in intronic, one in the promoter region and nine in the exonic region. The six novel mutations included mutations III, IV (in exon 6), IX (in UTR of exon 17), X, XI and XII (in intron of 4, 12 and 15). Rest of the seven mutations: I, II, V, VI, VII and VIII were already reported in different populations (Burger et al., 2007; Matthews et al., 2005; Enattah et al., 2008; Jarvela et al., 2003; Krawczyk et al., 2008; Morales et al., 2011; Rasinpera et al., 2004; Raz et al., 2013; Sahi et al., 1983; Sahi, 2001; Sebastio et al., 1989; Swallow, 2003; Szilagy et al., 2007; Tandon et al., 1981; Tarabra et al., 2010; Troelsen, 2005; Vesa et al., 2000). A cisacting factor present in the promoter region was studied at position -956 (mutation XIII). The results showed it at a higher frequency in lactose persistent group with $100 \%$ heterozygosity in both groups. As the mutations III, X, XII were also present at a frequency of " 1 " in the control group, their effect on the development of LNP was nullified. Mutations IV and IX were found at a frequency level of " 0.12 " in the same patients. The intronic region mutation: XI was found at a frequency of " 1 " in LNP and " 0 " in LP. The final change of amino acids was observed in four genomic mutations, but only mutation IV of exon 6, (nucleotide position 379) was novel in origin and was reported in LNP patients, mutation III was presented in both groups at same frequency levels. In intronic region, the mutation XI in intron 12 was found $100 \%$ in LNP patients, while among novel exonic mutations (IV and IX) only mutation IV was presented by $100 \%$ heterozygosity. All mutations are shown in Table II and Figures 3 and 5. In terms of frequency levels, only mutation IV, IX and XI were only reported in lactose Intolearant group. Rest were found at different frequencies in both groups i.e. LNP and LP. All exonic mutations were presented with heterozygosity of $20 \%$ to $100 \%$ in both groups, which was not the same in intronic region as shown in Table II.

\section{DISCUSSION}

LCT enzyme is formed as a protein, which is made up of 1927 amino acids and is further processed to a final main protein of 1059 amino acids (Matthews et al., 2005; Troelsen, 2005). Mutation of LCT-gene has been implicated in LNP, as reported in different earlier studies (Boll et al., 1991; Jarvela et al., 2003; Harvey et al., 1998; Hollox et al., 2001; Wang et al., 1995, 1998). Primers for exon 1, 2, 6, 10, 13 and 17 had a size of 953, 495, 925, 425, 376 and 410 bases, respectively, while the primers for promoter region had a size of 783, 953 and 980 bases, as shown in Table I (Jarvela et al., 2003; Johnson et al., 1993; Tishkoff et al., 2007) (NCBI dated 2.4.16 \&5.5.17). The already reported mutations occurred at codon 194, 219, 371, 473, 819, 1096, 1443, 1499, 1536, 1639 and 1856 in different exons of LCT gene (Boll et al., 1991; Harvey et al., 1998).

Later with the advancement in ongoing research, different studies reported the involvement of cis-acting factors in the nearby regions of $L C T$-gene and in the development of LP/ LNP in some populations (Boll et al., 1991; Montgomery et al., 1991). In one of the previous studies, the promoter region was also analyzed for its cisacting factor (Ranciaro et al., 2014). Our study confirmed the same codonic positions 194, 219, 362, 379, 473, 1639, 1856 of exon 1, 2, 6, 13 and 17 named as mutations I, II, V, VI, VII, VIII, and one promoter region named as mutation XIII at position-956 (Figs. 1, 2, 3, 4 and 5) (Harvey et al., 1998; Hollox et al., 2001; Wang et al., 1998).<smiles>C=C</smiles>

590 600 610 G A T G T T T C A T A T G T T T G AA T C T

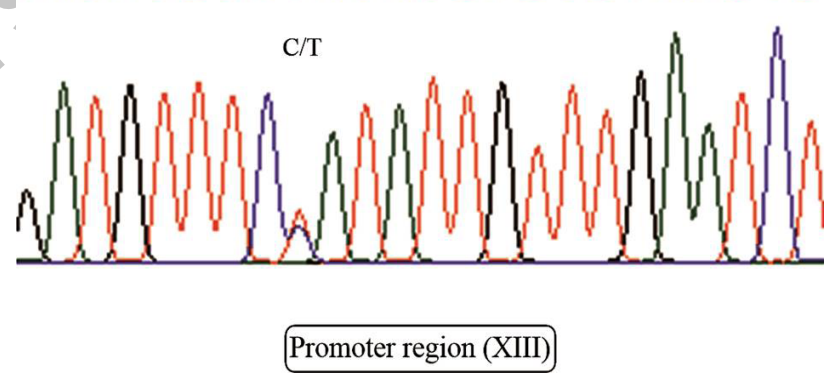

Fig. 4. Chromatograms of SNP in the $L C T$-gene promoter region.

LNP is the most common phenotype in human and its incidence varies as a function of ethnicity in different populations (Troelsen, 2005). It was found at a higher percentage in Southern Europe as compared to NorthWestern Europe (Sahi, 2001; Vesa et al., 2000). Likewise, North Americans were more LP as compared to African Americans with West African ancestry (Asmawi et al., 2006). In the Israeli and Afghani population, the incidence of lactose intolerant was found higher i.e. 82-97\% and $83 \%$, respectively (Rahimi et al., 1976). In a similar manner, Southern Indians were more LNP as compared to Northern Indians which are in the closest neighbourhood and are collectively considered as the descendants of Aryans (Asmawi et al., 2006; Tandon et al., 1981; Tomar, 2014). 


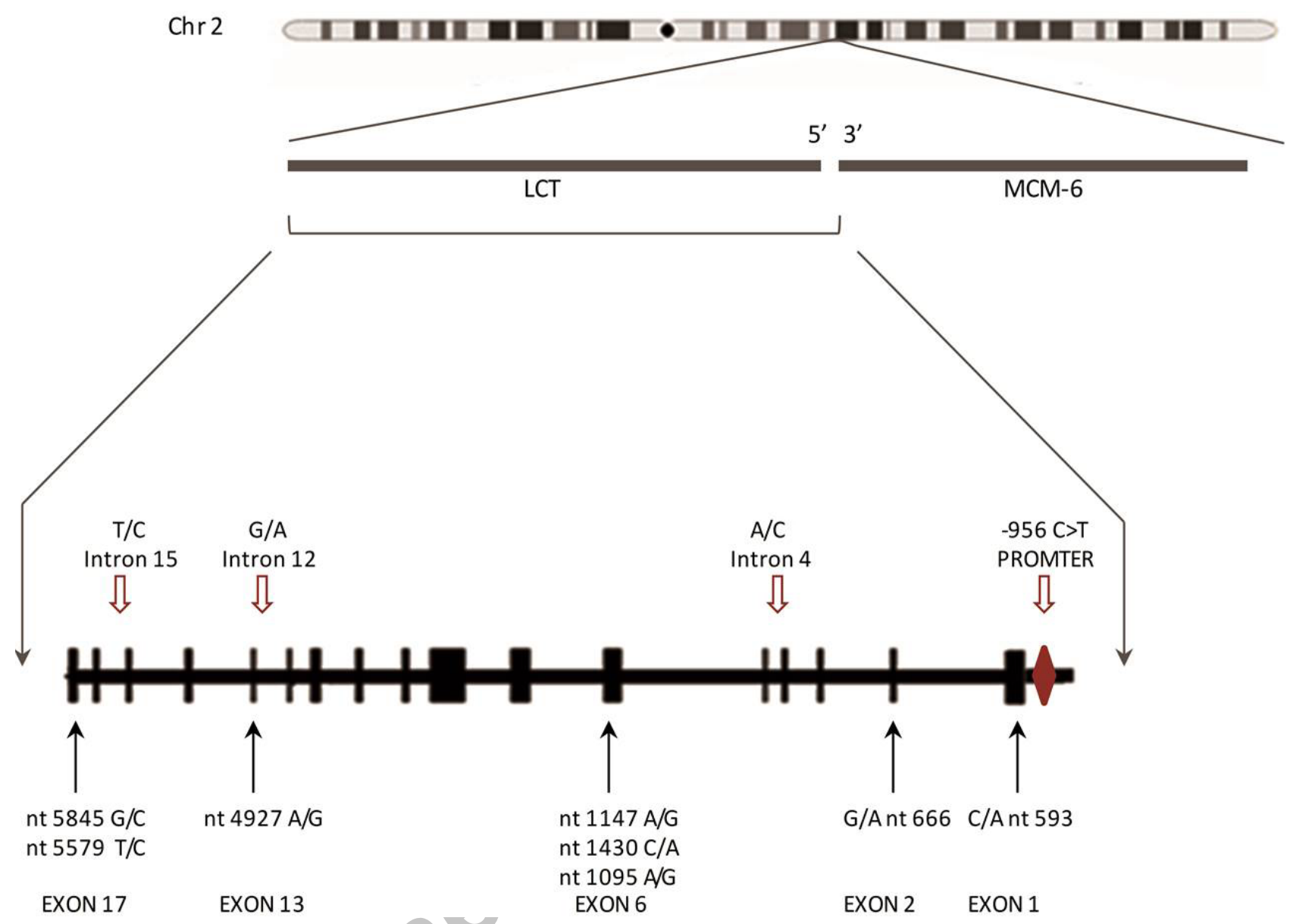

Fig. 5. Genetic variations in LCT-gene (McIntosh and Scheinfeldt, 2012).

In the current study, among the 12 mutations in $L C T$ gene, 3 were found in the intronic region and 2 in UTR. The rest of the 7 mutations caused the change of nucleotide in 3 codonic structures. Among the 7 mutations, three produced the same amino acids whereas the other four produced different amino acids.

Mutation I at position c.593 ACC $>$ ACT resulted in the production of Threonine even after a change of one nucleotide. Mutation V at position c.1430 GGC $>$ GGA produced Glycine with both codons. Mutation VII at position c.5779 (GCT $>$ GCC) coded for Alanine simultaneously. Mutation I was also considered to be involved in decreased production of lactase in correlation of transcriptional regulation (Boll et al., 1991; Jarvela et al., 2003; Wang et al., 1995, 1998; Betts et al., 2003). In the present study, it was found at 0.64 frequency level in LNP subjects and 20\% of heterozygosity. Mutation V was already reported (Betts et al., 2003; Boll et al., 1991) at encouraging levels of frequency in both LP and LNP groups. Mutation VII was found at a frequency of 0.644 in LNP and 1 in LP, which nullifies its relevance with mutational correlation.

The four important mutations, which resulted in the change of amino acids along with the final protein structure include mutations II, III, IV and VI. Mutation II GTT $>$ ATT at position c 666 caused the change of Valine to Iso-Leucine. This particular mutation is mostly observed in LP individuals. This mutation was also reported to act as a cis-acting factor on LCT-activity. It was also found involved in a population study for reporting 14 haplotypes (A to N) (Boll et al., 1991; Harvey et al., 1998; Hollox et al., 2001; Jarvela et al., 2003; Wang et al., 1995, 1998). Mutation II was observed at a frequency level of 0.67 in LP and at 0.34 in LNP patients with $100 \%$ heterozygosity in both groups. Thus, in order to have conclusive data for mutational analysis, we suggest including this exon on a larger scale. Mutation III at position c.1059 (ATC>GCT) which caused the production of valine from iso-leucine. Both mutations II and III are mirror images of each other. As Valine and Iso-Leucine both are non-polar/hydrophilic 
in nature. Mutation III, however, is novel in origin, but due to its occurrence at the same frequency level in both LNP and LP patients and homozygosity, its significance is nullified. Mutation IV was found at position c. 1147 $(\mathrm{CAG}>\mathrm{CGG})$, which is a missense mutation of novel origin. It resulted in the change of Glutamine to Arginine at a frequency level of 0.12 in LNP patients and zero in LP. Mutation VII had been reported at the same level as mutation II (Boll et al., 1991; Harvey et al., 1998; Hollox et al., 2001; Wang et al., 1998). Mutation VI at position c. 1430 (GCC $>$ GCA) resulted in a change of Asparginine to Serine. In current data analysis, mutation VI was observed at a frequency level of 0.64 in the LNP group, however, it could not be correlated to the development of LNP due to co-presence in the control group.

In the untranslated region, mutation No. VIII and IX were observed at position c.5845 $\mathrm{G}>\mathrm{C}$ and c.5865 $\mathrm{C}>\mathrm{T}$, respectively. Mutation VIII was already reported (Boll et al., 1991). Wang (1998) also aligned the data for the presence of heterozygosity along with the lactase sucrase activity, supporting cis-activity. The first variant was present in $100 \%$ of LNP and LP groups, having a frequency of " 1 " in both. Therefore, this mutation cannot be relied upon as one of the causes of the intolerant state (Boll et al., 1991; Hollox et al., 2001; Jarvela et al., 2003). The last mutation of the untranslated region was novel in origin and was found at a frequency of 0.12 in LNP group, whereas none of the LP group showed its presence. Mutation IV and IX (at exon 6 and 17) must be investigated at a larger population scale in order to deduce a conclusion. These two novel mutations were found at codon No. 379 and 1856 were observed in the same number of subjects $(12 \%)$ but only mutation IV caused the change of amino acid. It might affect the stability of the mRNA through missense mutation, by either causing decay or resulting in reduced expression of the protein. Although mutation IX was detected in only 6 subjects, it did not alter protein's amino acid composition, hence they might often prove significant in LNP. There is growing evidence that synonymous mutation (often erroneously referred to as silent) can affect transcription, splicing, mRNA transport and translation, any of which could alter phenotype, rendering the synonymous mutation non-silent and more important (Sauna et al., 2011).

Three novel mutations X, XI and XII were observed in introns 4, 12 and 15 of $L C T$-gene at positions: c. $(918+116)$ A $>$ C: g.15842 A>C, c. $(4877+20) \mathrm{G}>$ A: g. $39039 \mathrm{G}>\mathrm{A}$ and c. $(5346+35) \mathrm{T}>\mathrm{C}:$ g. $49004 \mathrm{~T}>\mathrm{C}$, respectively. The intronic variant, at position 4 and 15, was observed in both groups (lactose intolerant and lactose persistent). This occurrence may represent the mutational markers specifically present in Pakistan, however, their specific roll in correlation with LNP cannot be decided due to the equal presence $(100 \%)$ in both groups. The mutation at intron No. 12 was observed in 100\% LNP patients and was absent in the control group. This variant is of particular concern as it is present at the frequency of " 1 " in LNP, which shows that it may be used as a genetic marker for LNP indication while analyzing larger population data.

We detected one of the novel mutations in all LNP subjects in intron 12 (G39039A). Our sample size was rather small to conduct linkage equilibrium analysis in comparison to larger published studies. However, the fact that the other two new mutations were seen in $6 / 50$ cases indicates that further studies need to be conducted.

The identification of novel mutations in Exon 6, 17 and intron 12, is unique to Pakistani subjects from Punjab province and attributed to environmental factors and genetic variations amongst different racial/ethnic groups. Alternatively, it may be related to a lack of clinical studies on mutations in the $L C T$-gene along with the promoter region, other than those at codons 593, 666, 1430, 4927, 5579 and 5845 (Boll et al., 1991; Harvey et al., 1998; Jarvela et al., 2003).

The probable reason may be, that Dravidians were original inhabitants of our neighboring country India, Aryans established their cultures in the northern part and forced Dravidians to move to the southern part. The current Punjabis of Pakistan and North India are considered descendants of Aryans who had pastoralist backgrounds with the habit of regular milk consumption (Babu et al., 2010; Baseer and Rab, 1975; Simoons et al., 1978). Two studies were carried out using the conventional methods in Pakistan, both of them were contradictory to each other (Ahmad and Abhas, 1983; Baseer and Rab, 1975). Pasteurization and milking began in Punjab 5000 years ago, but due to cultivation trends of cereals, pulses and conversion of milk to other dairy products e.g. ghee, yogurt and butter, the selective mechanism may be correlated to LP in subjects belonging to Punjab (Pigott et al., 1977). The possibility of the introduction of the $L P$ gene to the Indian subcontinent by the migration of Aryan nomads exists but is not supported by data from Afghanistan and Iran, showing a relatively low incidence of LP (Rahimi et al., 1976).

$L C T$-promoter region is not sequenced in most of the earlier studies, however, in some recent studies, genetic analysis of this region has also been taken into account. In a study conducted in Africa, the association between LP trait development and mutation in the promoter region was found (Ranciaro et al., 2014). In this study, the mutation no. XIII in the promoter region was found at position c.$956 \mathrm{C}>\mathrm{T}$, and showed a frequency level of 0.36 to 0.67 in LNP / LP subjects with 100\% heterozygosity in both 
groups. The high frequency level in LP clearly indicates its vital role in the development of LP after weaning. Further investigation must be conducted with more emphasis on the role of Promoter and enhancer for lactase production. In recent studies, the genetic analysis of two cis-acting factors: C/T-13910, G/A-22018 at MCM-6 gene is presented as reliable genetic testing tools, they must also consider the LCT Promoter region. They can give more reliable results for the genetic screening of LNP/LP individuals, whereas the single nucleotide polymorphisms (SNPs) reported in exon 1 and 2 at positions 593 and 666, respectively may also regulate LCT expression and the enhancer effect of LCT-Promoter (Wang et al., 1995, 1998). Troelsen (2014) hypothesized that post-weaning decline/LNP is a result of a decrease in recruitment of transcriptional activators or increase recruitment of repressors in promoter of the $L C T$ gene (Enattah et al., 2007; Pigott et al., 1977).

In LNP individuals, avoidance of milk and milkcontaining products could result in low $\mathrm{Ca}^{+2}$ intake resulting in osteoporosis and fractures (AmirI et al., 2015; Beto, 2015; Escher et al., 1992; Flatz et al., 1973; Lewinsky et al., 2005; Gueguen et al., 2006; Sahi et al., 1978). The results of the current study give a firm foundation to the conclusion of high reliability on genetic markers or genetic testing for the diagnosis of LNP. That every patient with LNP should have information about the dietetic sources of lactose and instructions to regulate it on their own, in order to become symptom-free.

\section{CONCLUSION}

Introns, Exons and the Promoter region responsible for mutations are analyzed. The general public in Subcontinent is unfamiliar with illnesses such as Lactose Non-persistence. Thus a ratio of $40 \%$ of tested patients having LNP, indicates that there could be a significant relationship in LNP and Mutations of LCT-gene in Subcontinent, in contrast to other continents. A larger study sample should be tested for future works.

\section{ACKNOWLEDGMENTS}

The authors gratefully acknowledge the members of the Max-Planck Institute for Biophysical Chemistry, Gottingen, Germany for help in managing the sequencing PCR-results. The authors also thank Mr. Muhammad Bilal for assistance in compiling the results for $L C T$ Gene mutational analysis through STAT.

This work was supported by the "HEC Indigenous 5000 PhD Fellowship Program-Batch-VI" [grant no. 17-5-6/HEC-Ind-Sch/2010 dated 3 January 2011] and "International Research Support Initiative Program"
[grantno.1-8/HEC/HRD/2015/5148.PIN.IRSIP 30 BMS 24 Dated August 24th 2015].

Disclosure statement

No competing Financial intersets exists

Statement of conflict of interest

The authors have declared no conflict of interest.

\section{REFERENCES}

Ahmad, M. and Abbas, H., 1983. Persistence of high intestinal lactase activity in Pakistan. Hum. Genet., 64: 277-278. https://doi.org/10.1007/BF00279410

Amiri, I.M., Diekmann, L., von Köckritz-Blickwede, M. and Naim, H.Y., 2015. The diverse forms of lactose intolerance and the putative linkage to several cancers. Nutrients, 7: 7209-7230. https:// doi.org/10.3390/nu7095332

Asmawi, M., Seppo, L., Vapaatalo, H. and Korpela, R., 2006. Hypolactasia and lactose intolerance among three ethnic groups in Malaysia. Indian J. med. Res., 124: 697-704.

Babu, J., Kumar, S., Babu, P., Parasad, J.H. and Ghoshal, U.C., 2010. Frequency of lactose malabsorption among healthy Southern and Northern Indian populations by genetic analysis and lactose hydrogen breath and tolernace tests. Am. J. clin. Nutr., 91: 140-146. https://doi.org/10.3945/ ajcn.2009.27946

Baseer, A. and Rab, S.M., 1975. High intestinal lactase concentration in adult Pakistanis. Br. med. J., 2: 436. https://doi.org/10.1136/bmj.1.6007.436

Bayless, T. and Rosensweig, N.S., 1966. A racial difference in incidence of lactase deficiency. A survey of milk intolerance and lactase deficiency in healthy adult males. J. Am. med. Assoc., 197: 968972. https://doi.org/10.1001/jama.197.12.968

Beto, J.A., 2015. The role of calcium in human aging. Clin. Nutr. Res., 4: 1-8. https://doi.org/10.7762/ cnr.2015.4.1.1

Betts, M. and Michael, R.B., 2003. Amino acid properties and consequences of substitutions. In: Bioinformatics for geneticsists (eds. R. Michael and ICB Gray), Chapter 14. John Wiley \& Sons, Ltd., pp. 291-314.

Boll, W., Wagner, P. and Mantei, N., 1991. Structure of the chromosoml gene and cDNAs coding for lactase-phlorizin hydrolase in humans with adulttype hypolactasia or persistence of lactase. Am. J. Hum. Genet., 48: 889-902.

Burger, J., Kirchner, M., Bramanti, B., Haak, W. and 
Thomas, M.G., 2007. Absence of the lactase persistence-associated allele in early Neolithic Europeans. Proc. natl. Acad. Sci. U.S.A., 104: 37363741. https://doi.org/10.1073/pnas.0607187104

Cook, G.C., 1967. Lactase activity in newborn and infant Baganda. Br. med. J., 1: 527-530. https://doi. org/10.1136/bmj.1.5539.527

Cuatrecasas, P.L., Lockwood, D.H. and Caldwell, J.R., 1965. Lactase deficiency in the adult: A common occurance. Lancet, 1: 14-18. https://doi. org/10.1016/S0140-6736(65)90922-0

Dahlqvist, A., 1961. Determination of maltase and isomaltase activities with a glucose-oxidase reagent. Biochem. J., 80: 547-551. https://doi. org/10.1042/bj0800547

EFSA, 2010. Panel on dietetics products, nutrition and allergies (NDA). Scientific opinion on lactose thresholds in lactose intolearnce and galactosaemia. Eur. Fd. Safe. Auth. J., 8: 1777. https://doi. org/10.2903/j.efsa.2010.1777

Enattah, N.S., Trudeau, A., Pimenoff, V., Maiuri, L., Auricchio, S. and Greco, L., 2007. Evidence of still-ongoing convergence evolution of the lactase persistence T-13910 alleles in humans. Am. J. Hum. Genet., 81: 615-625. https://doi. org/10.1086/520705

Enattah, N.S., Jensen, T.G.K., Nielsen, M., Lewinski, R., Kuokkanen, M. and Rasinpera, H., 2008. Independent introduction of two lactase-persistence alleles into human populations reflects different history of adaptation to milk culture. Am. J. Hum. Genet., 82: 57-72.

Escher, J., Koning, N.D., Engen, C.G.J., Arora, S., Buller, H.A. and Montgomry, R.K., 1992. Molecular basis of lactase levels in adult humans. J. clin. Invest., 89: 480-483. https://doi.org/10.1172/JCI115609

Ferguson, A. and Maxwell, J.D., 1967. Genetic etiology of lactose intolernace. The Lancet, 290: 188-191. https://doi.org/10.1016/S0140-6736(67)90009-8

Flatz, G. and Rotthauwe, H.W., 1973. Lactose nutrition and natural selection. The Lancet, 2(7820): 76-77. https://doi.org/10.1016/S0140-6736(73)93267-4

Freund, J.N., Duluc, I. and Raul, F., 1989. Discrepancy between the intestinal lactase enzymatic activity and mRNA accumulation in sucklings and adults. Effect of starvation and thyroxine treatment. FEBS Lett., 248: 39-42. https://doi.org/10.1016/00145793(89)80427-2

Gray, G.M., Santiago, N.A., Colver, E.H. and Genel, M., 1969. Intestinal beta-galactosidases. II. Biochemical alteration in human lactase deficiency. J. clin. Invest., 48: 729-735. https://doi.org/10.1172/

\section{JCI106030}

Gueguen, L. and Pointillart, A., 2000. The bioavailability of dietary calcium. J. Am. Coll. Nutr., 19: 119S-136S.https:// doi.10.1080/0731572 4.2000.10718083.

Harvey, C.B., Hollox, E.J., Poulter, M., Wang, Y., Rossi, M. and Auricchio, S., 1998. Lactase haplotype frequencies in Caucasians: Association with the lactase persistence/non-persistence polymorphism. Annls Hum. Genet., 62: 215-223. https://doi. org/10.1046/j.1469-1809.1998.6230215.x

Hollox, E.J., Poulter, M., Zvarik, M., Ferak, V., Krause, A. and Jenkins, T., 2001. Lactase haplotype diversity in the Old World. Am. J. Hum. Genet., 68: 160-172. https://doi.org/10.1086/316924

Hovde, O. and Farup, P.G., 2009. A comparison of diagnostic tests for lactose malabsorption-which one is best? BMC Gastroenterol., 9: 82. https://doi. org/10.1186/1471-230X-9-82

Jarvela, I., Kuokkanen, M., Enattah, N.S., Oksanen, A., Salvilahti, E. and Orpana, A., 2003. Transcriptional regulation of the lactase-phlorizin hydrolase gene by polymorphisms associated with adult-type hypolactasia. GUT: Int. J. Gastroenterol. Hepatol., 52: 647-652. https://doi.org/10.1136/gut.52.5.647

Johnson, A.O., Semenya, J.G., Buchowski, M.S., Enwonwu, C.O. and Scrimshaw, N.S., 1993. Correlation of lactose maldigestion, lactose intolerance, and milk intolerance. Am. J. clin. Nutr., 57: 399-401. https://doi.org/10.1093/ajen/57.3.399

Krawczyk, M., Wolska, M., Schwartz, S., Gruenhge, F., Terjung, B. and Portincasa, P., 2008. Concordance of genetic and breath tests for lactose intolerance in a Tertiary Referral Centre. J. Gastrointest. Liver Dis., 17: 134-139.

Lee, M. and Krasinski, S.D., 1998. Human adultonset lactase decline: An update. Nutr. Rev., 56: 1-8. https://doi.org/10.1111/j.1753-4887.1998. tb01652.x

Lehtimaki, T., Rrontu, R., Hemminki, J., Mikkila, V., Rasanen, L. and Laaksonen, M., 2006. The effetcs of adult-type hypolactasia on body height growth and dietary calcium intake from cildhood into young adulthood: A 21y follow-up study-The cardiovascular risk in young finns study. Pediatrics, 118: $\quad 1553-1559 . \quad$ https://doi.org/10.1542/ peds.2006-0542

Lewinsky, R.H., Jensen, T.G.K., Møller, J., Stensballe, A., Olsen, J. and Troelsen, J.T., 2005. T-13910 DNA variant associated with lactase persistence interacts with Oct-1 and stimulates lactase promoter activity in vitro. Hum. Mol. Genet., 14: 3945-3953. https:// 
doi.org/10.1093/hmg/ddi418

Lukito, W., Malik, S.G., Surono, I.S. and Wahlqvist, M.L., 2015. From lactose intolerance to lactose nutrition. Asia-Pac. J. clin. Nutr., 24(Suppl 1): S18. https:// doi.10.6133/apjen.2015.24.s1.01

McIntosh, S.K. and Scheinfeldt, L.B., 2012. It's getting better all the time: Comparative perspectives from Oceania and West Africa on genetic analysis and archaeology. Afr. Archaeol. Rev., 29: 131-170. https://doi.org/10.1007/s10437-012-9122-Z

Matthews, S.B., Campbell, A.K., Waud, J.P. and Roberts, A.G., 2005. Systemic lactose intolerance:a new perspective on an old problem. Postgrad. med. J., 81: 167-173. https://doi.org/10.1136/ pgmj.2004.025551

Morales, E., Azocar, L., Maul, X., Perez, C., Chianale, J. and Miquel, J.F., 2011. The European lactase persistance genotype determines the lactase persistence state and correlates with gastrointestinal symptoms in the Hispanic and Amerindian Chilean population: A case-control and population-based study. Br. med. J. Open, 1: e000125. https://doi. org/10.1136/bmjopen-2011-000125

Montgomery, R.K., Büller, H.A., Rings, E.H.H.M. and Grand, R.J., 1991. Lactose intolerance and the genetic regulation of intestinal lactase-phlorizin hydrolase. FASEB J., 5: 2824-2832. https://doi. org/10.1096/fasebj.5.13.1916106

NCBI, 2014. LCT lactase, Gene ID: 3938. National Center For Biotechnology Information. Available at: www.ncbi.nlm.nih.gov/gene/3938 (acessed November 2017).

Pigott, S., Jalal, H., Merriam, A., Qayyum, A. and Stacey, T., 1977. The Indus Valley Civilization. Pakistan Stacey International, London, pp. 72.

Potter, J., Ho, M.W., Bolton, H., Furth, A.J., Swallow, D.M. and Griffiths, B., 1985. Human lactase and the molecular basis of lactase persistence. Biochem. Genet., 23: 423-439. https://doi.org/10.1007/ BF00499084

Rahimi, A., Delbrück, H., Haeckel, R., Goedde, H.W. and Flatz, G., 1976. Persistence of high intestinal lactase activity (lactose tolerance) in Afghanistan. Am. J. Hum. Genet., 34: 57-62. https://doi. org/10.1007/BF00284435

Ranciaro, A., Campbell, M.C., Jibril, B.H., Wen,Y.K., Froment, A. and Anagnostou, P., 2014. Genetic origins of lactase persistence and the spread of Pastoralism in Africa. Am. J. Hum. Genet., 94: 496510. https://doi.org/10.1016/j.ajhg.2014.02.009

Rasinpera, H., Savilahti, E., Enattah, N.S., Kuokkanen, M., Tötterman, N. and Lindahl, H., 2004. A genetic test which can be used to daignose adulttype hypolactasia in children. Gut, 53: 1571-1576. https://doi.org/10.1136/gut.2004.040048

Raz, M., Sharon, Y., Yerushalmi, B. and Birk, R., 2013. Frequency of LCT-13910 C/T and LCT-2201G/A single nucleotide polymophisms associated with adult-type hypolactasia/lactase persistence among Israelis of different ethnic groups. Gene, 519: 6770. https://doi.org/10.1016/j.gene.2013.01.049

Sahi, T., 2001. Genetics and epidemiology of adulttype hypolactasia with emphasis on the situation in Europe. J. Fd. Nutr. Res., 45: 161-162. https://doi. org/10.3402/fnr.v45i0.1799

Sahi T., Isokoski, M., Jussila, J., Launiala, K. and Pyörälä, K., 1973. Recessive inheritance of adulttype lactose malabsorption. Lancet, 2: 823-826. https://doi.org/10.1016/S0140-6736(73)90862-3

Sahi, T. and Launiala, K., 1978. Manifestation and occurrence of selective adult-type lactose malabsorption in Finnish teenagers: A follow-up study. Am. J. Digest. Dis., 23: 699-704. https://doi. org/10.1007/BF01072355

Sahi,T.,Launiala,K. and Laitinen,H., 1983.Hypolactasia in a fixed cohort of young Finnish adults: A followup study. Scand. J. Gastroenterol., 7: 865-870. https://doi.org/10.3109/00365528309182107

Sahi, T., 1978. Dietary lactose and the aetiology of human small-intestinal hypolactasia. Gut, 19: 1074-1086. https://doi.org/10.1136/gut.19.11.1074

Sambrook, J. and Russell, D., 2012. Molecular cloning: A laboratory manual III, Volume $1,4^{\text {th }}$ Edition. Cold Spring Press, Cold Spring Harbour.

Sauna,Z.E. and Kimchi-Sarfaty, C., 2011. Understanding the contribution of synonymous mutations to human disease. Nat. Rev. Genet., 12: 683-691. https://doi. org/10.1038/nrg3051

Sebastio, G., Villa, M., Sartorio, R., Guzzetta, V. and Poggi, V., 1989. Control of lactase in human adulttype hypolactasia and in weaning rabbits and rats. Am. J. Hum. Genet., 45: 489-497.

Simoons, F.J., 1978. The geographic hypothesis and lactose malabsorption. Am. J. Digest. Dis., 23: 963 980. https://doi.org/10.1007/BF01263095

Swallow, D.H., 2003. Genetic of lactase persistence and lactose intolerance. Annu. Rev. Genet., 37: 197-219. https://doi.org/10.1146/annurev. genet.37.110801.143820

Szilagy, A.M., Malolepszy, P., Hamard, E., Xue, X., Hilzenrat, N. and Ponniah, M., 2007. Comparison of a real-time polymerase chain reaction assay for lactase genetic polymorphism with standard indirect tests for lactose maldigestion. Clin. Gastroenterol. 
Hepatol., 5: 192-196. https://doi.org/10.1016/j. cgh.2006.06.009

Tandon, R.K., Joshi, Y.K., Singh, D.S., Narendranathan, M. and Balakrishnan, V., 1981. Lactose intolerance in North and South Indians. Am. J. clin. Nutr., 34: 943-946. https://doi.org/10.1093/ajcn/34.5.943

Tarabra, E., Pazienza, P., Borghesio, E., Actis, G.C., Tappero, G. and Framarin, L., 2010. LCT$13910 \mathrm{C}>\mathrm{T}$ polymorphism-associated lactose malabsorption and risk for colorectal cancer in Italy. Digest. Liver Dis., 42: 741-743. https://doi. org/10.1016/j.dld.2010.02.013

Tishkoff, S., Reed, F.A., Ranciaro, A., Voight, B.F., Babbitt, C.C. and Silverman, J.S., 2007. Convergent adaptation of human lactase persistence in Africa and Europe. Nat. Genet., 39: 31-40. https://doi. org/10.1038/ng1946

Tomar, B.S., 2014. Lactose intolerance and other disaccharidase deficiency. Indian J. Pediatr., 81: 876-886. https://doi.org/10.1007/s12098-0141346-2

Troelsen, J.T., 2005. Adult-type hypolactasia and regulation of lactase expression. Biochim. biophys.
Acta, 1723: 19-32. https://doi.org/10.1016/j. bbagen.2005.02.003

Vesa, T.H., Marteau, P. and Korpela, R., 2000. Lactose intolerance. J. Am. Coll. Nutr., 19: 165S-175S. https://doi.org/10.1080/07315724.2000.10718086

Wang, Y., Harvey, C.B., Pratt, W.S., Sams, V.R., Sarner, M. and Rossi, M., 1995. The lactase persistence/ non-persistence polymorphism is controlled by a cis-acting element. Hum. Mol. Genet., 4: 657-662. https://doi.org/10.1093/hmg/4.4.657

Wang, Y., Harvey, C.B., Hollox, E.J., Phillips, A.D., Poulter, M. and Clay, P., 1998. The genetically programmed down-regulation of lactase in children. Gastroenterology, 114: 1230-1236. https://doi. org/10.1016/S0016-5085(98)70429-9

Welsh, J.D., 1970. Isolated lactase deficiency in humans: Report on 100 patients. Medicine, 49: 257-278. https://doi.org/10.1097/00005792-19700700000001

Witte, J., Lloyd, M., Lorenzsonn, V., Korsmo, H. and Olsen, W., 1990. The biosynthetic basis of adult lactase deficiency. J. clin. Investig., 86: 1338-1342. https://doi.org/10.1172/JCI114843 